\title{
Peran Resep Elektronik dalam Meningkatkan Medication Safety pada Proses Peresepan di RSI Sultan Agung Semarang
}

Ferika Indrasari*, Ratna Wulandari, Dwi Nurul Anjayanti

Prodi Farmasi, Sekolah Tinggi Ilmu Farmasi Nusaputera, Semarang, Indonesia

*Corresponding author: ferikaindrasari89@gmail.com

Submitted: 28 September 2020

Accepted: 31 December 2020

Published: 09 April 2021

\begin{abstract}
Background: Medication error has been a concern due to its impact both financially and clinically. Prescribing error which is part of medication error must be prevented. Many interventions have been developed to prevent prescribing errors, including electronic prescribing (e-prescribing) systems. However, its use is limited especially in pharmacies and hospitals. Objective: This study aimed to determine the use of electronic prescriptions in improving medication safety for the outpatients at RSI Sultan Agung Semarang. Methods: This research used quantitative descriptive design to evaluate the prescribing errors. Data was analyzed using linier regression. The qualitative data was collected through interview to the clinicians regarding their opinion towards the e-prescribing system. Results: The results demonstrated that there was positive correlation between the electronic prescribing and medication safety as shown by the $R$ value and the R. Square value 0.583 and 0.340 , respectively. This means there is an effect of the independent variable (electronic prescribing) on the dependent variable (medication safety) by $34.0 \%$. In addition, the significancy value $(p<0.05)$ revealed that there was an influence of the electronic prescribing on the medication safety. The clinicans viewed electronic prescribing might increase medication safety. Conclusion: The electronic prescribing can improve medication safety during the prescribing process. The e-prescribing system also supports drug cycle management in ordering and delivering the drug to the patients.
\end{abstract}

Keywords: electronic prescription, medication safety, prescribing

\begin{abstract}
Abstrak
Pendahuluan: Medication error banyak mendapat perhatian karena dampaknya secara finansial maupun luaran klinik bagi pasien. Prescribing error sebagai bagian dari medication error merupakan kejadian yang seharusnya dapat dicegah. Banyak intervensi telah dikembangkan untuk mencegah prescribing error, antara lain dengan sistem resep elektronik (e-prescribing). Dalam proses peresepan resep elektronik masih banyak yang belum menggunakan sistem e-prescribing, terutama rumah sakit, puskesmas dan apotek. Tujuan: Penelitian ini bertujuan untuk mengetahui pengaruh penggunaan resep elektronik dalam meningkatkan medication safety pada proses peresepan pasien rawat jalan di RSI Sultan Agung Semarang. Metode: Penelitian ini merupakan jenis penelitian deskriptif kuantitatif dengan pengambilan data resep rawat jalan untuk mengevaluasi prescribing error. Data dianalisis menggunakan uji kausalitas dengan rumus regresi linier. Data kualitatif dengan melakukan wawancara kepada dokter untuk mengetahui penerimaan dokter terhadap sistem resep elektronik. Hasil: Hasil analisis korelasi menunjukkan bahwa bahwa terdapat hubungan yang positif antara peresepan elektronik dengan medication safety ditunjukkan oleh nilai korelasi/ hubungan (R) sebesar 0,583 dan koefesien determinasi (R Square) sebesar 0,340. Hal ini berarti pengaruh variabel bebas (resep elektronik) terhadap variabel terikat (medication safety) adalah sebesar $34,0 \%$. Selain itu terdapat tingkat signifikansi $\mathrm{p}<0,05$, maka ada pengaruh variabel Resep Elektronik (X) terhadap variabel Medication Safety (Y). Penerimaan dokter terhadap sistem resep elektronik sangat baik serta dapat meningkatkan keamananan bagi pasien. Kesimpulan: Resep elektronik berperan meningkatkan medication safety pada
\end{abstract}


proses peresepan. Dengan adanya sistem elektronik maka dapat meningkatkan akurasi peresepan, kewaspadaan terhadap potensi interaksi yang merugikan, riwayat alergi obat, dan efisiensi waktu pelayanan serta dapat meningkatkan keamananan bagi pasien.

Kata kunci: medication safety, peresepan, resep elektronik

\section{PENDAHULUAN}

Kesalahan pemberian obat merupakan kejadian yang dapat merugikan atau membahayakan pasien yang dilakukan oleh petugas kesehatan, khususnya dalam hal pengobatan pasien. Kejadian medication error dibagi dalam empat fase, yaitu fase prescribing, fase transcribing, fase dispensing, fase administering. Banyak organisasi kesehatan memfokuskan perhatian pada medication safety. The Institute of Medicine (IOM) melaporkan bahwa 32\%-69\% dari medication error adalah kejadian yang dapat dicegah (Kohn dkk., 2000). Suatu penelitian mengidentifikasi $3,40 \%$ dari kejadian adverse drug events dianggap menjadi penyebab pasien di rawat inap (Onder dkk., 2002).

American Society of Hospital Pharmacists (AHSP) mengelompokkan tipe medication error berdasarkan proses dalam penggunaan obat (medication use system) yang dibedakan secara praktis dalam beberapa tipe, yang salah satu diantaranya adalah prescribing error. Prescribing error didefinisikan sebagai kesalahan pemilihan obat. Kesalahan dapat berupa dosis, jumlah, indikasi, dan kontra indikasi pengobatan (ASHP, 1993).

Penyebab terjadinya prescribing error yang sering ditemukan adalah penulisan resep yang tidak jelas dan tidak lengkap (misalnya: dosis, jumlah, nama pasien), hal ini disebabkan karena pengetahuan dokter tentang ketersediaan obatobatan tidak terkonfirmasi dengan baik, tulisan yang buruk dan interupsi dari keluarga pasien (Susanti, 2013).

Berdasarkan Keputusan Menkes RI No.129/Menkes/SK/II/2008 tentang Standar Pelayanan Minimal Rumah Sakit, tidak adanya kejadian kesalahan pemberian obat sebesar $100 \%$, hal itu berarti bahwa seharusnya kejadian kesalahan pemberian obat atau medication error tidak boleh terjadi satupun dalam pelayanan kesehatan. Surat keputusan Menkes RI No.1027/Menkes/SK/IX/2004 menyebutkan bahwa kesalahan pemberian obat (medication error) adalah kejadian yang merugikan pasien, akibat pemakaian obat selama dalam penanganan kesehatan, yang sebetulnya dapat dicegah. Medication error dalam setiap kejadian dapat dihindari yang menyebabkan atau berakibat pada pelayanan obat yang tidak tepat atau membahayakan pasien sementara obat berada dalam pengawasan tenaga kesehatan atau pasien.

Peresepan elektronik dapat dihubungkan dengan akses elektronik lainnya seperti informasi farmasi, riwayat pengobatan pasien, catatan klinis, hasil lab, diagnosis klinis, dan status pasien. Peresepan elektronik memberikan akses informasi yang cepat sehingga membantu untuk memberi peringatan kepada dokter tentang obat alternatif yang dapat diberikan kepada pasien, dan informasi tentang interaksi obat yang mungkin terjadi, peningkatan efek obat yang merugikan pasien, serta memberikan informasi tentang ketidaktaatan pasien dalam pengobatan (Schleiden dkk., 2015).

Pada tahun 2014 didapatkan hasil bahwa ketidaklengkapan penulisan resep lebih tinggi secara bermakna pada resep non elektronik dibandingkan resep elektronik (OR 1,30 ; 95\% CI: 1,06-1,58). Tulisan tidak terbaca secara bermakna hanya pada resep non elektronik 91 resep. Risiko kejadian interaksi obat dan adanya kesalahan yang lain berupa pemilihan obat tidak tepat, polifarmasi dan dosis tidak lazim tidak berkurang dengan resep elektronik. Faktor- faktor lain yang mempengaruh prescribing error adalah latar belakang profesi dokter, usia pasien, adanya racikan dan jumlah jenis obat dalam resep. Lebih dari $50 \%$ dokter setuju dan sangat setuju terhadap persepsi kemudahan dan persepsi manfaat resep elektronik (Susi dkk., 2014).

Pada penelitian yang telah dilakukan sebelumnya oleh Susi dkk. (2014) tentang peran resep elektronik dalam meningkatkan medication safety pada proses peresepan tahun 2014 didapatkan hasil bahwa ketidaklengkapan penulisan resep lebih tinggi secara bermakna pada resep non elektronik dibandingkan resep elektronik (OR 1,30 ; 95\% CL 1,06 - 1,58), sehingga perlu dilakukan penelitian tentang peran resep elektronik dalam meningkatkan medication safety pada proses peresepan. Oleh karena itu penelitian ini bertujuan untuk mengetahui pengaruh 
penggunaan resep elektronik dalam meningkatkan medication safety pada proses peresepan pasien rawat jalan di RSI Sultan Agung Semarang.

\section{BAHAN DAN METODE}

\section{Desain penelitian}

Penelitian ini merupakan jenis penelitian deskriptif kuantitatif dengan pengambilan data resep rawat jalan (resep elektronik) untuk mengevaluasi prescribing error. Data dianalisa menggunakan uji kausalitas dengan rumus regresi linier. Data kualitatif dengan melakukan wawancara kepada dokter untuk mengetahui penerimaan dokter terhadap sistem resep elektronik.

\section{Tempat dan waktu penelitian}

Penelitian ini dilakukan di Instalasi Farmasi Rawat Jalan RSI Sultan Agung Semarang dan waktu penelitian pada bulan Februari-April 2020

\section{Populasi dan sampel}

Populasi yang digunakan sebagai objek penelitian adalah seluruh resep elektronik rawat jalan 3 sub spesialis dasar yang masuk ke Instalasi Farmasi RSI Sultan Agung Semarang. Sampel penelitian dipilih dari resep rawat jalan 3 sub spesialis dasar (spesialis penyakit jantung, spesialis penyakit saraf, dan spesialis penyakit dalam) yang masuk ke Instalasi Farmasi RSI Sultan Agung Semarang periode bulan Februari sampai April tahun 2020. Jumlah sampel diambil dengan menggunakan rumus slovin :

$$
\begin{aligned}
\mathrm{n} & =\mathrm{N} /\left(1+\left(\mathrm{N} \mathrm{x} \mathrm{e}^{2}\right)\right) \\
& =10.049 /\left(1+\left(10.049 \times 0,05^{2}\right)\right) \\
& =384
\end{aligned}
$$

(Sugiyono, 2016)

\section{Variabel penelitian}

Variabel bebas pada penelitian ini adalah semua resep elektronik rawat jalan dari 3 sub spesialis dasar yang masuk ke pelayanan pasien rawat jalan di instalasi farmasi RSI Sultan Agung Semarang. Variabel terikat pada penelitian ini adalah medication safety pada proses peresepan. Prescribing error sebagai kesalahan pemilihan obat, Kesalahan dapat berupa dosis, jumlah, indikasi, aturan pakai, dan kontra indikasi pengobatan.

Instrumen yang digunakan berupa instrumen yang digunakan berupa penginputan nama obat, aturan pakai, dan perintah lain/iter. Parameter yang digunakan yaitu kriteria tidak lengkap (prescriptio, signature dan subcriptio), ada interaksi obat dengan obat, pemilihan obat yang tidak tepat (nama obat, aturan pakai) dan dosis tidak lazim (berat badan) (Kohn dkk., 2000).

\section{Teknik analisis data}

Data-data yang didapat kemudian dianalisis secara deskriptif kuantitatif dan kualitatif. Untuk mengetahui pengaruh resep elektronik pada medication safety menggunakan uji kausalitas dengan analisis data regresi linier. Pengukuran yang dilakukan dalam penelitian ini menggunakan skala Guttman untuk mendapatkan jawaban jelas dan konsisten terhadap pengaruh resep elektronik pada medication safety.

\section{HASIL DAN PEMBAHASAN}

Pada bulan Februari - April 2020 total sampel resep rawat jalan 384 lembar resep elektronik dari 2.396 resep elektronik dengan menggunakan rumus slovin. Pada penelitian ini menggunakan resep elektronik berdasarkan karakteristik resep kemudian dari setiap lembar resep dilihat kelengkapan resep. Aspek kelengkapan resep meliputi incriptio (tanggal penulisan resep), invocatio (tanda $\mathrm{R} /$ ), prescriptio (komposisi obat, sediaan obat), signatura (nama, umur, alamat pasien, aturan pakai), dan subcrioptio (tanda tangan/paraf dokter). Aspek kelengkapan resep yang tidak lengkap dikhawatirkan dapat memicu terjadinya medication error (Marini dkk., 2013).

Berdasarkan Tabel 1 menjelaskan bahwa 2 - 4 obat diresepkan pada 33,07\% pasien dengan jumlah resep $12,90 \%$ lebih kecil dibandingkan dengan peresepan > 4 jenis obat dengan jumlah pasien $66,93 \%$ dan jumlah resep $87,10 \%$. Prescribing error dapat terjadi apabila pasien mendapatkan terapi obat $>4$ jenis obat (ASHP, 1993). Resep racikan diberikan pada 1 pasien dengan jumlah resep $0,17 \%$ lebih kecil dibandingkan dengan jenis obat non racikan jumlah pasien $99,74 \%$ dengan jumlah resep 99,92\%, hal ini dikarenakan resep non-racikan mendominasi pada peresepan yang diterima selama periode Februari s.d April 2020 terutama pada pasien berusia di atas 40 tahun. Data yang diambil berasal dari kelompok umur > 40 tahun yang kebanyakan mendapat terapi obat jadi (tidak racikan). Usia juga merupakan predisposisi terjadinya efek samping obat, di mana efek samping obat banyak terjadi pada pasien dewasa dan lanjut usia dibandingkan dengan pasien anak. Hal ini berhubungan dengan jumlah obat yang di konsumsi serta lamanya menggunakan obat, khususnya untuk terapi jangka panjang. Pasien usia lanjut cenderung menerima beberapa obat sekaligus dalam proses terapinya sehubungan dengan sakit yang timbul secara bersamaan. Terjadi peningkatan efek samping 
hingga 7 kali, yaitu $3 \%$ dan $21 \%$ pada pasien berusia 20 - 30 tahun dan 60 - 70 tahun (Koh dkk., 2005). Oleh karena itu, polifarmasi dan usia merupakan kombinasi yang sangat menimbulkan Drug Related Problem (DRP). Hal ini yang menyebabkan pasien lanjut usia cenderung mengalami ME.

Tabel 1. Karakteristik resep elektronik periode Februari s.d. April 2020

\begin{tabular}{ccccc}
\hline Karakter resep & \multicolumn{3}{c}{ Jumlah pasien n (\%) } & \multicolumn{2}{c}{ Jumlah resep n (\%) } \\
\hline Jumlah obat & & & 309 & $12,90 \%$ \\
$2-4$ & 127 & $33,07 \%$ & 2.087 & $87,10 \%$ \\
$>4$ & 257 & $66,93 \%$ & 4 & $0,17 \%$ \\
\hline Jenis resep racikan & 1 & $0,30 \%$ & 2.392 & \\
\hline Tidak racikan & 383 & $99.74 \%$ & 1.169 & $48,79 \%$ \\
\hline Dokter penulis resep & 130 & $33,85 \%$ & 678 & $28,30 \%$ \\
Spesialis Jantung & & & 459 & $22,91 \%$ \\
\hline Spesialis Saraf & 136 & $35,42 \%$ & & \\
\hline Spesialis Penyakit Dalam & 118 & $30,73 \%$ & 312 & $13,02 \%$ \\
\hline Kelompok umur pasien & & & 2.084 & $86,98 \%$ \\
\hline $\begin{array}{l}15 \\
\text { - 40 th }\end{array}$ & 70 th & $19,53 \%$ & 2.396 & \\
\hline Jumlah & 309 & $80,47 \%$ & &
\end{tabular}

Dari hasil data Tabel 2 prescribing error data resep yang tidak lengkap $41,67 \%$ dan $23,00 \%$, ada interaksi obat $10 \%$ dan $38,94 \%$, pemilihan obat tidak tepat $33,63 \%$ dan $4,42 \%$, sedangkan tulisan resep yang tidak terbaca $0 \%$. Prescribing error lebih besar terjadi pada resep tidak lengkap (prescriptio, signature dan subcriptio), pemilihan obat tidak tepat (nama obat dan aturan pakai), dan adanya interaksi obat.

Tabel 2. Prescribing error berdasarkan jumlah pasien dan jumlah resep

\begin{tabular}{lcc}
\hline Berdasarkan jumlah pasien & $\mathrm{n}=384$ & $\%$ \\
\hline \multicolumn{1}{c}{ Prescribing error } & 60 & $15,63 \%$ \\
\hline Tidak lengkap & 25 & $41,67 \%$ \\
Ada interaksi & 6 & $10 \%$ \\
Pemilihan obat tidak tepat & 24 & $40 \%$ \\
Dosis tidak lazim & 5 & $8,30 \%$ \\
\hline Berdasarkan jumlah resep & $\mathrm{n}=2.396$ & $\%$ \\
\hline \multicolumn{1}{c}{ Prescribing error } & 113 & $4,72 \%$ \\
\hline Tidak lengkap & 26 & $23,00 \%$ \\
Ada interaksi & 44 & $38,94 \%$ \\
Tulisan tidak terbaca & 0 & $0,00 \%$ \\
Pemilihan obat tidak tepat & 38 & $33,63 \%$ \\
Dosis tidak lazim & 5 & $4,42 \%$ \\
\hline
\end{tabular}

Ketidaklengkapan dan ketidakjelasan penulisan dalam bagian resep yakni incriptio, invocatio, prescriptio, signatura, subcriptio dan pro dapat menyebabkan terjadinya medication error (Mamarimbing dkk., 2012).

Pada proses peresepan peran resep elektronik di RSI Sultan Agung Semarang prescribing error resep elektronik berdasarkan jumlah pasien dan jumlah resep yang diteliti sangat kecil sehingga peran resep elektronik dalam proses peresepan dapat menurunkan terjadinya medication error. Hal ini sejalan dengan penelitian yang dilakukan sebelumnya oleh Susi dkk. (2014) tentang peran resep elektronik dalam meningkatkan medication safety pada proses peresepan tahun 2014 didapatkan hasil bahwa ketidaklengkapan penulisan resep lebih tinggi secara bermakna pada resep non elektronik dibandingkan resep elektronik (OR 1,30 ; 95\% CL 1,06-1,58).

Prescribing error berdasarkan kelompok dokter dilihat dari ketidaklengkapan resep, interaksi obat, resep tidak terbaca dan dari faktor error lain jumlah resep dokter poli saraf dan poli dalam lebih kecil dari pada dokter poli jantung dikarenakan jumlah jenis obat peresepan dokter jantung $>4$ jenis obat dan pasien yang periksa rata-rata umur di atas 40 tahun, sehingga terjadinya prescribing error lebih 
besar dibandingkan dokter poli saraf dan dokter poli dalam. Yang berarti bahwa prescribing error lebih besar terjadi pada pasien yang menerima obat $>4$ jenis obat serta umur $>40$ tahun sehingga dapat dikatakan bahwa proses peresepan pasien rawat jalan peran resep elektronik dapat meningkatkan medication safety.

Tabel 3. Prescribing error berdasarkan kelompok umur pasien

\begin{tabular}{lcc}
\hline \multicolumn{1}{c}{$\begin{array}{c}\text { Berdasarkan } \\
\text { Jumlah R/ }\end{array}$} & $\begin{array}{c}\text { R/ Pasien } 15-40 \text { th } \\
(\mathrm{n}=312)\end{array}$ & $\begin{array}{c}\mathrm{R} / \text { Pasien }>40 \text { th } \\
(\mathrm{n}=2,084)\end{array}$ \\
\hline Ketidaklengkapan & & \\
Tidak lengkap & 13 & 37 \\
Lengkap & 299 & 2.047 \\
Interaksi obat & & \\
Ada interaksi & 18 & 26 \\
Tidak ada interaksi & 294 & 2.058 \\
Tidak terbaca & & \\
Tidak terbaca & 0 & 0 \\
Terbaca & 312 & 2.084 \\
Ada error lain & & \\
Tidak ada & 300 & 2.058 \\
Ada & 12 & 26 \\
\hline
\end{tabular}

Faktor lain yang berpengaruh terhadap kejadian prescribing error adalah kelompok umur pasien pada Tabel 3. Hasil menunjukkan bahwa prescribing error lebih besar terjadi pada umur $>40$ th karena jumlah resep obat terapi yang diterima pasien $>4$ jenis obat. Berdasarkan Rambhade dkk. (2011) jumlah macam obat yang berlebihan dalam satu resep (polifarmasi) juga berkontribusi terhadap risiko terjadinya medication error.

Dari hasil prescribing error berdasarkan jumlah pasien, jumlah resep, kelompok dokter penulis resep serta kelompok umur pasien diperoleh data prescribing error lebih besar terjadi pada ketidaklengkapan resep (prescriptio), adanya interaksi obat serta pemilihan obat yang tidak tepat sehingga dapat digunakan untuk menganalisis data regresi linier sederhana prescribing error yang terjadi.

Berdasarkan hasil uji normalitas terhadap skala resep elektronik diperoleh nilai tes statistik 0,492 dengan taraf sigifikan $0,000(\mathrm{p}<0,05)$. Hal tersebut menunjukkan bahwa sebaran data resep elektronik memiliki distribusi yang tidak normal. Sehingga model regresi belum memenuhi asumsi normalitas.

Uji linieritas diperlukan untuk mengetahui hubungan antara variabel bebas dengan variabel terikat. Berdasarkan uji linieritas pada distribusi skala resep elektronik terhadap medication safety diperoleh nilai hasil uji signifikasi $\mathrm{P}=0,000$ ( $\mathrm{p}<$ $0,05)$. Persamaan regresi $Y=-0,620+1,150 X$ yang diperoleh berdasarkan data penelitian adalah signifikan, atau model persamaan regresi memenuhi kriteria. Dengan demikian, dapat disimpulkan bahwa secara simultan terdapat pengaruh yang signifikan antara resep elektronik terhadap medication safety.

Pada pengujian hipotesis berdasarkan perhitungan regresi linier sederhana menunjukkan hasil penelitian nilai yang diperoleh adalah signifikansi dimana nilai $\mathrm{P}=0,000(\mathrm{p}<0,05)$. Nilai tersebut dapat membuktikan hipotesis diterima yang berarti bahwa "Ada pengaruh yang positif dan signifikan secara parsial antara variabel resep elektronik terhadap medication safety". Dari hasil uji $\mathrm{R}^{2}$, diperoleh nilai adjusted $\mathrm{R}^{2}$ sebesar 0,338 atau $33,8 \%$. Hal ini menunjukkan bahwa resep elektronik hasil analisis pada tabel di atas menjelaskan besarnya nilai korelasi/hubungan $(\mathrm{R})$ yaitu sebesar 0,583 . Berarti bahwa pengaruh variabel bebas (resep elektronik) terhadap variabel terikat (medication safety) sebesar 33,8\%, sedangkan sisanya dipengaruhi oleh variabel yang lain. Sehingga dapat di tafsirkan bahwa peresepan elektronik berkontribusi sebesar $33,8 \%$ terhadap medication safety.

\section{KESIMPULAN}

Terdapat pengaruh penggunaan resep elektronik dalam meningkatkan medication safety pada proses peresepan pasien rawat jalan di RSI Sultan Agung Semarang dengan nilai korelasi/hubungan (R) yaitu 
sebesar 0,583 dan koefesien determinasi sebesar 33,8\% yang mempunyai pengaruh variabel bebas (resep elektronik) terhadap variabel terikat (medication safety) adalah sebesar 33,8\%. Resep elektronik dapat meningkatkan medication safety pada proses peresepan. Dengan adanya sistem elektronik dapat memudahkan proses pemesanan obat, waktu pemesanan obat lebih singkat dan cepat, serta dapat meningkatkan keamananan yang safety bagi pasien.

\section{UCAPAN TERIMAKASIH}

Artikel ini telah dipaparkan pada kegiatan seminar nasional dan temu ilmiah di Fakultas Farmasi Universitas Airlangga tanggal 26 September 2020.

\section{DAFTAR PUSTAKA}

American Society of Hospital Pharmacist (ASHP). (1993). ASHP Guidelines on Preventing Medication error in Hospital. Maryland: American Society of Hospital Pharmacist.

Kohn, L., Corrigan, J. \& Donaldson, M. (2000). To Err is Human: Building a Safer Health System. Washington DC: National Academy Pess.

Koh, Y., Kutty, F. B. M., Li, S. C. 2005. Drug-Related Problem in Hospitalized Patients on Polypharmacy: The Influence of Age and Gender. Therapeutics an Clinical Risk Management. 1(1): 39-48

Marini, Iswahyudi \& Wjianto, B. (2013). Analisa Kelengkapan Penulisan Resep dari Aspek Kelengkapan Resep di Apotek Kota Pontianak Tahun 2012. Jurnal Mahasiswa Farmasi Fakultas Kedokteran UNTAN; 1; 1-10.
Mamarimbing, M., Fatimawal \& Bodhi, W. (2012). Evaluasi Kelengkapan Adminitratif Resep dari Dokter Spesialis Anak pada Tiga Apotek di Kota Manado. Pharmacon; 1; 46-51.

Onder, G., Pedone, C., Landi, F., Cesari, M., Vedova, C. D., Bernabei, R. \& Gambassi, G. (2002). Adverse Drug Reactions as Cause of Hospital Admissions: Results from the Italian Group of Pharmacoepidemiology in the Elderly (GIFA). Journal of the American Geriatrics Society; 50; 1962-1968.

Rambhade, S., Chakarborty, A., Shrivastava, A., Patil, U. K. \& Rambhade, A. (2011). A Survey on Polypharmacy and Use of Innappropriate Medication. Toxicology Internasional; 19; 68-73.

Schleiden, L., Odukoya, O. \& Chui, M. (2015). Older Adults Perceptions of E-Prescribing: Impact on Patient Care. Perspectives in Health Information Management; 12; 1-15.

Sugiyono. (2016). Metode Penelitian Kuantitatif, Kualitatif, dan R\&D. Bandung: Alfabeta, CV.

Susanti, I. (2013). Identifikasi Medication Error Pada Fase Prescribing, Transcribing, dan Dispensing di Depo Farmasi Rawat Inap Penyakit Dalam Gedung Teratai, Instalasi Farmasi RSUP Fatmawati. Skripsi; Fakultas Kedokteran dan Ilmu Kesehatan UIN Syarif Hidayatullah, Jakarta.

Susi, M. W \& Dwiprahasto Iwan. (2014). Peran Resep Elektronik dalam Meningkatkan Medication Safety pada Proses Peresepan. Jurnal Manajemen Pelayanan Kesehatan UGM; 17; 01; 30-36. 